\title{
Interaction of Aldosterone and Extracellular Volume in the Pathogenesis of Obesity- Associated Kidney Disease: A Narrative Review
}

\author{
Andrew S. Bomback Philip J. Klemmer \\ UNC Kidney Center, Department of Medicine, Division of Nephrology and Hypertension, University of North \\ Carolina at Chapel Hill, Chapel Hill, N.C., USA
}

\section{Key Words}

Aldosterone $\cdot$ Extracellular volume $\cdot$ Obesity $\cdot$ Chronic

kidney disease

\begin{abstract}
Obesity and obesity-associated kidney injuries have played an important role in the rising prevalence of chronic kidney disease (CKD). The link between obesity and kidney disease begins with obesity's well-known associations with diabetes and hypertension, the two leading etiologies of CKD. However, a growing body of evidence suggests that elevated aldosterone levels and expanded extracellular volume are key components of obesity-induced renal disease via aldosterone's non-epithelial effects on the kidney. Highlighting these blood pressure- and diabetes-independent mechanisms of kidney injury in obesity allows an exploration of whether mineralocorticoid receptor blockade, coupled with weight loss and salt restriction, is an optimal treatment for overweight CKD patients.

Copyright $\odot 2009$ S. Karger AG, Base
\end{abstract}

\section{Introduction}

Chronic kidney disease (CKD) is associated with premature mortality, decreased quality of life, and increased healthcare expenditures. The prevalence of CKD has risen at an alarming rate, with recent estimates suggesting that approximately $17 \%$ of the US adult population has CKD $[1,2]$. While the growing burden of diabetes and hypertension, in conjunction with the general ageing of the population, has contributed to the increased prevalence of CKD, the obesity epidemic has also played a significant role [3].

Over the last three decades, obesity prevalence has more than doubled among US adults. In the most recent National Health and Nutrition Examination Survey (NHANES), $32.2 \%$ of US adults met the clinical criteria for obesity with a body mass index (BMI) of $\geq 30$ [4]. The rising prevalence of obesity has been matched by a parallel increase in the prevalence of metabolic syndrome. This clinical syndrome, marked by abdominal obesity, hypertriglyceridemia, low HDL cholesterol, elevated blood pressure, and impaired insulin sensitivity, is detectable in roughly 1 in 3 US adults [5]. Therefore, any discussion of the renal effects of obesity and metabolic syndrome must begin with diabetes and hypertension, which together account for roughly $70 \%$ of CKD $[1,2]$.

The vast majority of hypertensive and diabetic patients are either overweight or obese, and rising BMI is inversely related to control of disease. Among diabetic patients, for example, obesity is associated with poorer control of blood glucose, blood pressure, and cholesterol, heightening the risk for macrovascular (i.e. cardiac) and microvascular (i.e. renal) complications [6]. In fact, much of the attention paid to obesity as a risk factor for kidney disease has aptly focused on its links to diabetes and hy-

\section{KARGER}

Fax +4161306 1234 E-Mail karger@karger.ch www.karger.com (c) 2009 S. Karger AG, Basel

0250-8095/09/0302-0140\$26.00/0

Accessible online at:

www.karger.com/ajn
Andrew S. Bomback, MD

University of North Carolina Kidney Center

7011-E Burnett-Womack Building, Campus Box 7155

Chapel Hill, NC 27599-7155 (USA)

Tel. +1 919966 2561, ext. 220, Fax +1 919966 4251, E-Mail abomback@unch.unc.edu 
pertension. Nevertheless, a growing body of evidence has emerged suggesting that obesity by itself - independent of its association with hypertension and/or diabetes - is a key player in renal injuries [7-12]. In this narrative review, we examine the evidence that the interaction of aldosterone and extracellular volume is a crucial component of obesity-associated kidney disease.

\section{Obesity-Induced Kidney Injury Independent of Hypertension and Diabetes}

A number of recent clinical and epidemiological studies suggest that obesity itself - independent of its ties to diabetic and hypertensive disease risk - can play an important role in the development of CKD. A multivariate, cross-sectional analysis of NHANES data found a graded association between higher BMI and reduced kidney function (measured by serum cystatin C), with odds ratios (95\% CI) of elevated serum cystatin C of $1.46(1.02-2.10)$ for overweight (BMI 25.0-29.9), 2.36 (1.56-3.57) for class I obesity (BMI 30.0-34.9), and $2.82(1.56-5.11)$ for class II-III obesity (BMI $\geq 35.0)$ [13]. Pooled data from the Atherosclerosis Risk in Communities Study (ARIC) and Cardiovascular Health Study (CHS) demonstrated that waistto-hip ratio (WHR), a preferred anthropomorphic measure of obesity, was a better predictor than BMI of incident CKD [14]. A Turkish study of 110 otherwise healthy obese patients (i.e. non-diabetic, non-hypertensive) showed a significant and independent association between BMI and CKD that may be due to occult inflammation given the correlation between elevated BMI and C-reactive protein levels in this study [15]. And a prospective cohort of 8,792 healthy Korean men without known risk factors for CKD found that increases in body weight, even when the BMI remained within normal range, were independently associated with increased risk for CKD [16].

The recent study by Serra et al. [17] deserves special mention for the novelty of its methods in examining the obesity-CKD relationship. These investigators performed kidney biopsies on 95 extremely obese (i.e. BMI $\geq 40$ ) patients without clinical signs of renal dysfunction who were undergoing bariatric surgery. Only about half of these patients were hypertensive, and less than $15 \%$ were diabetic. The renal biopsies revealed a variety of glomerular lesions, including increased mesangial matrix, mesangial cell proliferation, podocyte hypertrophy, and glomerulomegaly. The investigators propose that the early lesions found in this study are potential harbingers of future overt kidney disease.

Aldosterone, Extracellular Volume, and Obesity
A number of mechanisms have been proposed as explanations for the obesity-CKD relationship, including chronic inflammation, abnormal vascular remodeling, and renal lipotoxicity [7]. These routes of injury can occur in the absence of diabetes and hypertension, although the comorbidities likely exacerbate the damage. Perhaps the best described mechanism of obesity-induced kidney injury involves the adverse effects of increased body mass and subsequent increased glomerular filtration rate (GFR) per intact nephron. A hyperfiltration injury ensues, as obesity induces, even at 'normal nephron capacity', the adaptations characteristic of reduced nephron number in CKD [18]. Another proposed mechanism involves adiponectin, a hormone produced by adipocytes that regulates glucose and lipid metabolism. This adipocytokine is decreased in obesity, with levels of adiponectin shown to be inversely related to the degree of albuminuria in obese patients $[19,20]$. Adiponectin knockout mice have profound proteinuria and, on histology, foot process effacement that both improve with exogenous adiponectin treatments [21]. The end result of these kidney injury pathways can be a proteinuric kidney disease termed obesity-associated glomerulopathy, which on histology ranges from glomerulomegaly alone to a secondary focal segmental glomerulosclerosis pattern [22].

\section{Non-Epithelial Effects of Aldosterone}

Over the last decade, aldosterone has emerged as a key agent in the pathophysiology of progressive kidney disease $[23,24]$. In addition to its classic, epithelial effects of promoting sodium retention (and potassium and magnesium excretion), aldosterone activates mineralocorticoid receptors in non-epithelial tissues of the heart, peripheral vasculature, and kidney to foster inflammation and fibrosis. These non-epithelial, injurious effects of aldosterone occur in the presence of normal to high sodium cofactor, defined as high sodium intake with expanded extracellular volume [25]. The harmful interaction between aldosterone and expanded extracellular volume may be a key component of the pathogenesis of obesityinduced kidney injury.

In animal models, unopposed aldosterone in the presence of high salt intake causes proteinuria via thrombotic and proliferative lesions in the glomeruli and renal vessels [26-29]. These pathologic lesions occur independent of blood pressure, reflecting a direct, non-epithelial, proinflammatory, profibrotic effect of aldosterone on the kidney. Observational human studies have also high-

Am J Nephrol 2009;30:140-146 
lighted the interplay between aldosterone and extracellular volume in renal injuries. In the Primary Aldosteronism Prevalence in Italy (PAPY) study, for example, despite essentially equal blood pressures and sodium intakes, subjects with primary aldosteronism had significantly higher albuminuria rates than essential hypertensive subjects with low to normal aldosterone levels [30]. In other studies among resistant hypertensive subjects, higher aldosterone levels were correlated with higher degrees of proteinuria; moreover, among the high aldosterone subjects, the elevations in proteinuria were linearly related to 24-hour urinary sodium levels (a surrogate for extracellular volume) $[31,32]$. Thus, while hyperaldosteronism and expanded extracellular volume can, individually, be risk factors for kidney injury, their combined presence likely exhibits a multiplicative effect [33]. This pathological milieu likely exists in obesity.

\section{Hyperaldosteronism of Obesity}

Obesity and the metabolic syndrome are frequently associated with elevated levels of aldosterone [34-39], and intentional weight loss typically reduces aldosterone levels [40, 41]. Adipocytes express a renin-angiotensin system and are consequently able to produce angiotensin II, traditionally the key stimulator of adrenal production of aldosterone [42, 43]. This fat-based renin-angiotensin system, however, is likely only one component of aldosterone overproduction in obesity. Excess adipose tissue appears to provide a medium in which aldosterone secretion is further stimulated by angiotensin II-independent routes.

Obesity is characterized by increased plasma fatty acids and oxidative stress; the most readily oxidized fatty acids are the polyunsaturated acids, the most abundant of which is linoleic acid. Goodfriend et al. [44] tested the effects of oxidized derivatives of linoleic acid on rat adrenal cells. One derivative, 12,13-epoxy-9-keto-10(trans)octadecenoic acid, was particularly potent, stimulating aldosteronogenesis at concentrations from 0.5 to $5 \mu \mathrm{mol} / \mathrm{l}$. This experiment suggests that, in the obese state, oxidized fatty acids likely stimulate aldosteronogenesis independent of physiological control by angiotensin II and volume status.

Ehrhart-Bornstein et al. [45] created a fat cell-conditioned medium to test the hypothesis that adipocyte secretory products directly stimulate adrenocortical aldosterone secretion. In vitro, human adrenocortical cells were placed in this fat cell-conditioned medium and, in a 24-hour incubation period, increased aldosterone secretion 7-fold. Concomitant incubation with the angiotensin receptor blocker, valsartan, did not significantly reduce this aldosterone secretion, confirming that the aldosterone-stimulating effect was not angiotensin IImediated. At least two mineralocorticoid-releasing factors - an active (MW $>50 \mathrm{kDa}$ ) and an inactive (MW $<50$ $\mathrm{kDa}$ ) fraction - were identified by fractionation of the fat cell medium, but these investigators were not able to further categorize these potent, adipocyte-secreted aldosterone-stimulating factors [45].

Complement-Clq TNF-related protein 1 (CTRP1), a member of the CTRP superfamily, may turn out to be one of these mineralocorticoid-releasing factors. In an experiment with obese, diabetic rats, Jeon et al. [46] recently investigated stimulation of aldosterone production by CTRP1, which is expressed at high levels in adipose tissue and in the zona glomerulosa of the adrenal cortex, the site of aldosterone production. In addition to finding a dosedependent increase in aldosterone production by CTRP1, they also found that angiotensin II-induced aldosterone production was, at least in part, mediated by the stimulation of CTRP1 secretion [46].

These pathophysiological links between visceral adiposity and aldosterone secretion suggest that obese patients may be constitutively stimulated to produce aldosterone, and obesity can thus be viewed as a state of relative hyperaldosteronism. For example, in the study by Gaddam et al. [32] of 279 resistant hypertensive patients, the mean BMI was 33.0, the mean plasma aldosterone was $13.0 \mathrm{ng} / \mathrm{dl}$, and the mean urine aldosterone was 13.0 $\mu \mathrm{g} / 24 \mathrm{~h}$. Given that these obese subjects' mean urinary sodium excretion was $187 \mathrm{mEq} / 24 \mathrm{~h}$, these values suggest disordered aldosterone regulation, with the average patient in the study essentially meeting clinical criteria for primary aldosteronism (urine aldosterone $>12.0 \mu \mathrm{g} / 24 \mathrm{~h}$ with urine sodium $>200 \mathrm{mEq} / 24 \mathrm{~h}$ ) [47].

\section{Obesity and Expanded Extracellular Volume}

Obesity and the metabolic syndrome are states of impaired sodium excretion [48]. This natriuretic handicap is likely caused by insulin resistance and/or hyperglycemia, as increased filtered glucose stimulates tubular reabsorption of filtered sodium [49]. An alternative theory is that the hyperfiltration of obesity causes a concomitant hyperactivity of the proximal tubule, with subsequent excessive sodium reabsorption [50]. The impaired sodium excretion in obesity has been postulated as the root of 
obesity-associated hypertension [51, 52]. In this case, the combination of retained sodium and increased aldosterone works via traditional epithelial routes to raise blood pressure and potentially damage the kidney.

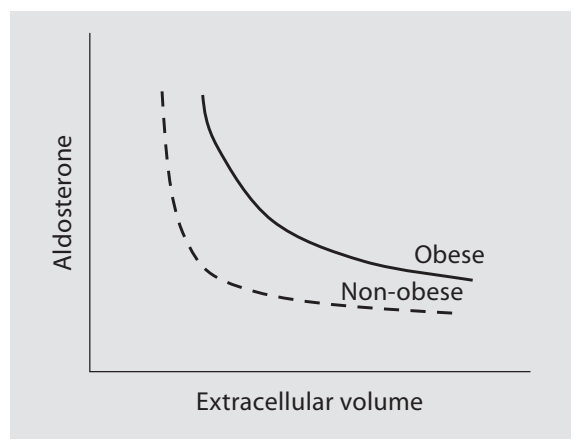

Fig. 1. Proposed relationship between aldosterone and extracellular volume in obese and non-obese individuals. These aldosterone-volume curves are based on the aldosterone-sodium curves reported by Brunner et al. [70]. The expansion of extracellular volume, which typically occurs via a salt load, should lead to suppression of aldosterone levels as represented by the dashed line. Obese individuals (solid line), however, possess a natriuretic handicap and therefore are hypothesized to be subject to both higher states of extracellular volume and, for such states, relatively higher aldosterone levels compared to the non-obese.
Yet potentially more harmful to the kidney are the non-epithelial effects of aldosterone and expanded extracellular volume, the sequelae of sodium retention. Because obesity is characterized by both relative hyperaldosteronism and expanded volume, an obese individual is chronically subjected to higher degrees of the volume-aldosterone interaction than a non-obese individual (fig. 1). In other words, the obese individual not only has a defective salt-excreting mechanism, but also has a relatively defective renin-angiotensin-aldosterone system, unable to suppress aldosterone levels in response to extracellular volume expansion as effectively as a non-obese individual. The result of these parallel defects - a 'double hit' of expanded volume and relative hyperaldosteronism - can be fibrosis, inflammation, and, ultimately, end-organ damage in the kidney (fig. 2).

Speculatively, this 'double hit' theory of expanded volume and relative hyperaldosteronism may be particularly important in African-Americans, an ethnic group with high prevalences of hypertension and obesity. Hypertension is typically more severe in African-Americans than in whites, with higher morbidity and mortality, including progression to end-stage kidney disease $[53,54]$. In a study of 234 African-Americans and 279 white French Canadians, African-Americans with and without hypertension had significantly higher BMI, waist circumfer-
Fig. 2. Obesity is characterized by elevated aldosterone and expanded extracellular volume. While oxidized fatty acids and adipokines stimulate aldosterone production from the adrenal gland, the hyperglycemia and insulin resistance of the metabolic syndrome impose a natriuretic handicap and subsequent volume expansion. This harmful interaction of inappropriately elevated aldosterone and expanded extracellular volume is the 'double hit' of obesity, leading to activation of non-epithelial mineralocorticoid receptors in the kidney. The resulting inflammation and fibrosis can lead to end-organ damage with glomerulosclerosis and proteinuria. This route of kidney injury occurs independent of obesity's well-known links to kidney disease via diabetes, hypertension, and dyslipidemia.

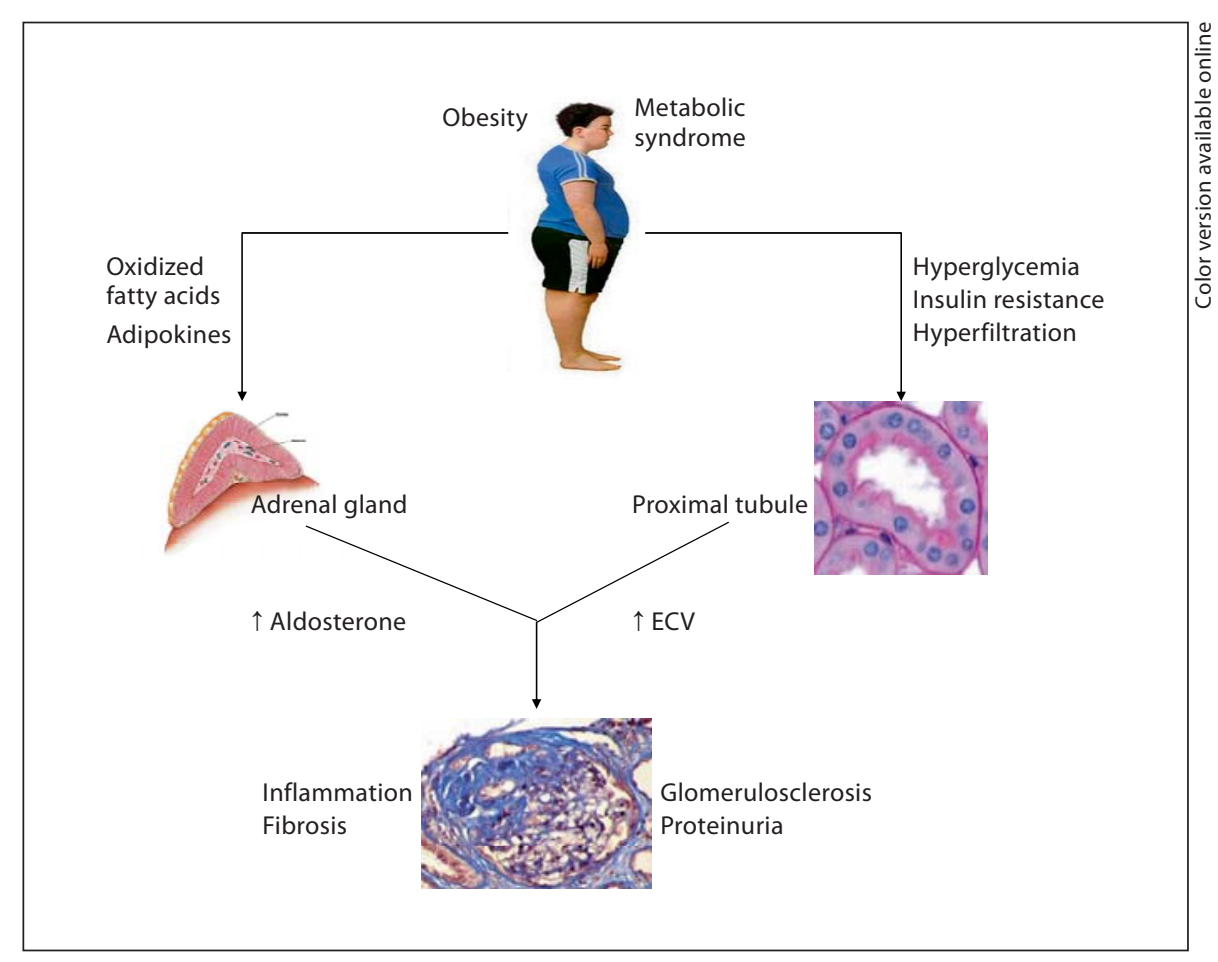


ence, and percent body fat than their French Canadian counterparts [55]. Among the hypertensive subjects in this study, African-Americans also had lower plasma renin activity (PRA, an inverse measurement of volume status), higher aldosterone levels, and higher aldosterone/PRA ratios than whites: 26.2 versus 8.4 when supine, 27.4 versus 8.0 when standing $(p<0.0001$ for both comparisons). Another report from these same investigators, studying 397 African-Americans of whom roughly half were hypertensive, identified the metabolic syndrome in $17 \%$ of all subjects [56]. The prevalence of hypertension in metabolic syndrome subjects was $94 \%$ compared to $37 \%$ in subjects without metabolic syndrome, and metabolic syndrome subjects had significantly higher aldosterone levels, lower PRA levels, and higher aldosterone/PRA ratios. This group recently published data on 217 normotensive and 224 hypertensive African-Americans, in which hypertensive subjects, with mean BMI of $28.9 \pm 0.3$ compared to $27.2 \pm 0.3$ in normotensives $(\mathrm{p}<0.0001)$, again manifested markedly higher aldosterone and lower PRA levels than their leaner, normotensive counterparts [57]. This 'mild variant of primary aldosteronism' (a phrase used by these authors) was associated with reduced vascular compliance and increased renal vascular resistance. Overall, African-Americans with overweight and obesity appear to be at high risk for high aldosterone and low renin levels that suggest a hyperaldosterone and hypervolemic state. While elevated blood pressures play a key role in the resultant hypertensive end-organ damage, injuries to the heart and kidney may also be due, in part, to the blood-pressure independent, non-epithelial effects of aldosterone in this milieu of expanded volume and relative hyperaldosteronism.

\section{Treating Obesity-Associated Kidney Disease}

Fortunately, therapies exist that may prevent or at least attenuate some of the renal injuries of obesity by blocking aldosterone and/or reducing extracellular volume. Perhaps the best therapy is simple weight loss which, as noted above, leads to decreased aldosterone levels as well as improved glycemic and blood pressure control $[6,40,41]$. A salt-restricted diet is another treatment option that can address volume expansion, as are diuretics. To date, there have been no prospective studies on the effects of bariatric surgery on kidney function, but theoretically such an intervention should benefit the kidney from the standpoint of both extracellular volume and aldosterone. Re- cent retrospective analyses suggest that bariatric surgery leads to improvements in glomerular filtration rate and reductions in albuminuria in patients with preexisting kidney disease $[58,59]$. Aldosterone levels were not reported in these patients, but the concomitant reductions in high-sensitivity C-reactive protein levels suggest that weight loss surgery reduced overall inflammation and that the renal benefits were not solely due to blood pressure reduction [60].

The role of aldosterone in obesity-related kidney injury is crucial when considering pharmacological treatment options. Angiotensin-converting enzyme (ACE) inhibitors have been shown to ameliorate podocyte damage in obese rats, perhaps through downstream suppression of aldosterone [61]. Mineralocorticoid receptor blockers, such as spironolactone and eplerenone, which target both the epithelial and non-epithelial effects of aldosterone, have shown very promising results in animal studies of obesity-associated kidney disease. In dogs fed a high fat diet, simultaneous treatment with eplerenone (compared with untreated animals) markedly attenuated obesity-induced glomerular hyperfiltration, sodium retention, and hypertension [62]. Proteinuria in a rat model of metabolic syndrome was correlated with aldosterone levels and accompanied histologically by podocyte injury that, along with proteinuria, markedly improved after administration of mineralocorticoid receptor blockade [63-65]. Two small clinical studies, both currently in abstract form, have shown that mineralocorticoid receptor blockade significantly reduces urinary protein excretion [66, 67]. Notably, the mean pretreatment aldosterone levels of subjects in both studies were greater than mean population aldosterone values [68], supporting the notion that obesity is a hyperaldosterone state and highlighting why direct aldosterone blockade may have been so effective in these patients.

Ideally, all obese patients should try to lose weight - by diet, surgery, or both measures. However, given how difficult it can be to achieve and maintain substantial weight loss, we also suggest checking obese patients' aldosterone levels, particularly if there is clinical evidence of renal dysfunction (which would include proteinuria and difficult to manage hypertension). If the aldosterone concentration is normal to elevated, a mineralocorticoid receptor blocker and salt restriction could be prescribed for renal protection. Alternatively, empiric treatment with mineralocorticoid receptor blockers and a low-salt diet may be undertaken even without aldosterone measurements, recognizing the possibility that mineralocorticoid receptor activation may also occur via elevated cortisol 
concentrations in obesity [69]. Importantly, such prescriptions for mineralocorticoid receptor blockers in obesity should be balanced against the drugs' increased risk for hyperkalemia, particularly when estimated GFR is $<60 \mathrm{ml} / \mathrm{min} / 1.73 \mathrm{~m}^{2}$.

\section{Conclusion}

Obesity is a rising cause of kidney injury. Targeting its associated comorbidities of diabetes and hypertension should confer some renal protection, but there is grow- ing evidence that obesity and the metabolic syndrome can injure the kidney via blood pressure- and diabetesindependent mechanisms. As obesity is a state characterized by both relative hyperaldosteronism and expanded extracellular volume, obese individuals are primed for renal injuries via aldosterone's non-epithelial, profibrotic, proinflammatory effects. Weight loss and salt restriction are crucial interventions to attenuate obesityinduced kidney injuries. Mineralocorticoid receptor blockade may also emerge as a staple treatment for this disease.

\section{References}

1 Centers for Disease Control and Prevention (CDC): Prevalence of chronic kidney disease and associated risk factors - United States, 1999-2004. MMWR Morb Mortal Wkly Rep 2007;56:161-165.

$\checkmark 2$ Coresh J, Selvin E, Stevens LA, Manzi J, Kusek JW, Eggers P, Van Lente F, Levey AS: Prevalence of chronic kidney disease in the United States. JAMA 2007;298:2038-2047.

$>$ Hallan SI, Vikse BE: Relationship between chronic kidney disease prevalence and endstage renal disease risk. Curr Opin Nephrol Hypertens 2008;17:286-291.

4 Ogden CL, Carroll MD, Curtin LR, McDowell MA, Tabak CJ, Flegal KM: Prevalence of overweight and obesity in the United States, 1999-2004. JAMA 2006;295:1549-1555.

$\checkmark 5$ Ford ES: Prevalence of the metabolic syndrome defined by the international diabetes federation among adults in the US. Diabetes Care 2005;28:2745-2749.

-6 Anderson JW, Kendall CW, Jenkins DJ: Importance of weight management in type $2 \mathrm{di}$ abetes: review with meta-analysis of clinical studies. J Am Coll Nutr 2003;22:331-339.

7 Praga M: Obesity - a neglected culprit in renal disease. Nephrol Dial Transplant 2002; 17:1157-1159.

8 Hall JE, Henegar JR, Dwyer TM, Liu J, Da Silva AA, Kuo JJ, Tallam L: Is obesity a major cause of chronic kidney disease? Adv Ren Replace Ther 2004; 11:41-54.

-9 Ejerblad E, Fored CM, Lindblad P, Fryzek J, McLaughlin JK, Nyren O: Obesity and risk for chronic renal failure. J Am Soc Nephrol 2006;17:1695-1702

10 Wahba IM, Mak RH: Obesity and obesityinitiated metabolic syndrome: mechanistic links to chronic kidney disease. Clin J Am Soc Nephrol 2007;2:550-562.

$\checkmark 11$ Cignarelli M, Lamacchia O: Obesity and kidney disease. Nutr Metab Cardiovasc Dis 2007;17:757-762.

>12 Griffin KA, Kramer H, Bidani AK: Adverse renal consequences of obesity. Am J Physiol Renal Physiol 2008;294:F685-F696.
13 Muntner P, Winston J, Uribarri J, Mann D, Fox CS: Overweight, obesity, and elevated serum cystatin C levels in adults in the United States. Am J Med 2008;121:341-348.

14 Elsayed EF, Sarnak MJ, Tighiouart H, Griffith JL, Kurth T, Salem DN, Levey AS, Weiner DE: Waist-to-hip ratio, body mass index, and subsequent kidney disease and death. Am J Kidney Dis 2008;52:29-38.

15 Bavbek N, Isik B, Kargili A, Uz E, Uz B, Kanbay M, Turgut F, Karakurt F, Akcay A: Association of obesity with inflammation in occult chronic kidney disease. J Nephrol 2008;21:761-767.

16 Ryu S, Chang Y, Woo HY, Kim SG, Kim DI, Kim WS, Suh BS, Choi NK, Lee JT: Changes in body weight predict CKD in healthy men. J Am Soc Nephrol 2008;19:1798-1805.

-17 Serra A, Romero R, Lopez D, Navarro M, Esteve A, Perez N, Alastrue A, Ariza A: Renal injury in the extremely obese patients with normal renal function. Kidney Int 2008;73: 947-955.

18 Bagby SP: Obesity-initiated metabolic syndrome and the kidney: a recipe for chronic kidney disease? J Am Soc Nephrol 2004; 15: 2775-2791.

19 Rasouli N, Kern PA: Adipocytokines and the metabolic complications of obesity. J Clin Endocrinol Metab 2008;93:S64-S73.

20 Yano Y, Hoshide S, Ishikawa J, Hashimoto T, Eguchi K, Shimada K, Kario K: Differential impacts of adiponectin on low-grade albuminuria between obese and nonobese persons without diabetes. J Clin Hypertens (Greenwich) 2007;9:775-782.

21 Sharma K, Ramachandrarao S, Qiu G, Usui HK, Zhu Y, Dunn SR, Ouedraogo R, Hough K, McCue P, Chan L, Falkner B, Goldstein BJ: Adiponectin regulates albuminuria and podocyte function in mice. J Clin Invest 2008;118:1645-1656.

22 Kambham N, Markowitz GS, Valeri AM, Lin J, D’Agati VD: Obesity-related glomerulopathy: an emerging epidemic. Kidney Int 2001; 59:1498-1509.
23 Epstein M: Aldosterone as a mediator of progressive renal disease: pathogenetic and clinical implications. Am J Kidney Dis 2001; 37:677-688

24 Hostetter TH, Ibrahim HN: Aldosterone in chronic kidney and cardiac disease. J Am Soc Nephrol 2003;14:2395-2401.

25 Sato A, Saruta T: Aldosterone-induced organ damage: plasma aldosterone level and inappropriate salt status. Hypertens Res 2004;27: 303-310.

26 Greene EL, Kren S, Hostetter TH: Role of aldosterone in the remnant kidney model in the rat. J Clin Invest 1996;98:1063-1068.

27 Rocha R, Chander PN, Zuckerman A, Stier CT Jr: Role of aldosterone in renal vascular injury in stroke-prone hypertensive rats. Hypertension 1999;33:232-237.

-28 Rocha R, Stier CT Jr, Kifor I, Ochoa-Maya MR, Rennke HG, Williams GH, Adler GK: Aldosterone: a mediator of myocardial necrosis and renal arteriopathy. Endocrinology $2000 ; 141: 3871-3878$.

29 Hollenberg NK: Aldosterone in the development and progression of renal injury. Kidney Int 2004;66:1-9.

$>30$ Rossi GP, Bernini G, Desideri G, Fabris B, Ferri C, Giacchetti G, Letizia C, Maccario M, Mannelli M, Matterello MJ, Montemurro D, Palumbo G, Rizzoni D, Rossi E, Pessina AC, Mantero F: Renal damage in primary aldosteronism: results of the PAPY study. Hypertension 2006;48:232-238.

- 31 Pimenta E, Gaddam KK, Pratt-Ubunama MN, Nishizaka MK, Aban I, Oparil S, Calhoun DA: Relation of dietary salt and aldosterone to urinary protein excretion in subjects with resistant hypertension. Hypertension 2008;51:339-344.

32 Gaddam KK, Nishizaka MK, Pratt-Ubunama MN, Pimenta E, Aban I, Oparil S, Calhoun DA: Characterization of resistant hypertension: association between resistant hypertension, aldosterone, and persistent intravascular volume expansion. Arch Intern Med 2008;168:1159-1164. 
\$3 Klemmer PJ, Bomback AS: Extracellular volume and aldosterone interaction in chronic kidney disease. Blood Purif 2009;27:92-98.

>34 Goodfriend TL, Egan BM, Kelley DE: Aldosterone in obesity. Endocr Res 1998;24:789796.

35 Bochud M, Nussberger J, Bovet P, Maillard MR, Elston RC, Paccaud F, Shamlaye C, Burnier M: Plasma aldosterone is independently associated with the metabolic syndrome. Hypertension 2006;48:239-245.

-36 Bentley-Lewis R, Adler GK, Perlstein T, Seely EW, Hopkins PN, Williams GH, Garg R: Body mass index predicts aldosterone production in normotensive adults on a highsalt diet. J Clin Endocrinol Metab 2007;92: 4472-4475

>37 Krug AW, Ehrhart-Bornstein M: Aldosterone and metabolic syndrome: is increased aldosterone in metabolic syndrome patients an additional risk factor? Hypertension 2008;51:1252-1258.

>38 Rossi GP, Belfiore A, Bernini G, Fabris B, Caridi G, Ferri C, Giacchetti G, Letizia C, Maccario M, Mannelli M, Palumbo G, Patalano A, Rizzoni D, Rossi E, Pessina AC, Mantero F: Body mass index predicts plasma aldosterone concentrations in overweightobese primary hypertensive patients. J Clin Endocrinol Metab 2008;93:2566-2571.

-39 Mule G, Nardi E, Cusimano P, Cottone S, Seddio G, Geraci C, Palermo A, Andronico G, Cerasola G: Plasma aldosterone and its relationships with left ventricular mass in essential hypertensive patients with the metabolic syndrome. Am J Hypertens 2008;21: 1055-1061

40 Tuck ML, Sowers J, Dornfeld L, Kledzik G, Maxwell M: The effect of weight reduction on blood pressure, plasma renin activity, and plasma aldosterone levels in obese patients. N Engl J Med 1981;304:930-933.

-41 Engeli S, Bohnke J, Gorzelniak K, Janke J, Schling P, Bader M, Luft FC, Sharma AM: Weight loss and the renin-angiotensin-aldosterone system. Hypertension 2005;45:356362.

42 Engeli S, Sharma AM: The renin-angiotensin system and natriuretic peptides in obesity-associated hypertension. J Mol Med 2001;79:21-29.

43 Sharma AM, Engeli S, Pischon T: New developments in mechanisms of obesity-induced hypertension: role of adipose tissue. Curr Hypertens Rep 2001;3:152-156.

44 Goodfriend TL, Ball DL, Egan BM, Campbell WB, Nithipatikom K: Epoxy-keto derivative of linoleic acid stimulates aldosterone secretion. Hypertension 2004;43:358-363.

-45 Ehrhart-Bornstein M, Lamounier-Zepter V, Schraven A, Langenbach J, Willenberg HS, Barthel A, Hauner H, McCann SM, Scherbaum WA, Bornstein SR: Human adipocytes secrete mineralocorticoid-releasing factors. Proc Natl Acad Sci USA 2003;100:1421114216 .
46 Jeon JH, Kim KY, Kim JH, Baek A, Cho H, Lee YH, Kim JW, Kim D, Han SH, Lim JS, Kim KI, Yoon do Y, Kim SH, Oh GT, Kim E, Yang Y: A novel adipokine CTRP1 stimulates aldosterone production. FASEB J 2008; 22:1502-1511.

47 Funder JW, Carey RM, Fardella C, GomezSanchez CE, Mantero F, Stowasser M, Young WF Jr, Montori VM: Case detection, diagnosis, and treatment of patients with primary aldosteronism: an endocrine society clinical practice guideline. J Clin Endocrinol Metab 2008;93:3266-3281.

48 Rocchini AP, Katch V, Kveselis D, Moorehead C, Martin M, Lampman R, Gregory M Insulin and renal sodium retention in obese adolescents. Hypertension 1989;14:367-374.

49 Nosadini R, Sambataro M, Thomaseth K, Pacini G, Cipollina MR, Brocco E, Solini A, Carraro A, Velussi M, Frigato F, et al: Role of hyperglycemia and insulin resistance in determining sodium retention in non-insulindependent diabetes. Kidney Int 1993;44: 139-146.

50 Chagnac A, Herman M, Zingerman B, Erman A, Rozen-Zvi B, Hirsh J, Gafter U: Obesity-induced glomerular hyperfiltration: its involvement in the pathogenesis of tubular sodium reabsorption. Nephrol Dial Trans plant 2008;23:3946-3952.

51 Hall JE, Brands MW, Hildebrandt DA, Mizelle HL: Obesity-associated hypertension. Hyperinsulinemia and renal mechanisms. Hypertension 1992;19:I45-I55.

52 Vogt B, Bochud M, Burnier M: The association of aldosterone with obesity-related hypertension and the metabolic syndrome. Semin Nephrol 2007;27:529-537.

53 Klag MJ, Whelton PK, Randall BL, Neaton JD, Brancati FL, Stamler J: End-stage renal disease in African-American and white men. 16-year MRFIT findings. JAMA 1997;277: 1293-1298.

54 Flack JM, Ferdinand KC, Nasser SA: Epidemiology of hypertension and cardiovascular disease in African Americans. J Clin Hypertens (Greenwich) 2003;5:5-11.

55 Grim CE, Cowley AW Jr, Hamet P, Gaudet D, Kaldunski ML, Kotchen JM, Krishnaswami S, Pausova Z, Roman R, Tremblay J, Kotchen TA: Hyperaldosteronism and hypertension: ethnic differences. Hypertension 2005;45: 766-772.

56 Kidambi S, Kotchen JM, Grim CE, Raff H, Mao J, Singh RJ, Kotchen TA: Association of adrenal steroids with hypertension and the metabolic syndrome in blacks. Hypertension 2007;49:704-711.

57 Kotchen TA, Kotchen JM, Grim CE, Krishnaswami S, Kidambi S: Aldosterone and alterations of hypertension-related vascular function in African Americans. Am J Hypertens 2009;22:319-324.

58 Navaneethan SD, Yehnert H, Beddhu S: Bariatric surgery in chronic kidney disease: does it halt progression? J Am Soc Nephrol 2008; 19:528A.
59 Agrawal V, Khan I, Rai B, Krause KR, Chengelis DL, Zalesin KC, Rocher LL, McCullough PA: The effect of weight loss after bariatric surgery on albuminuria. Clin Nephrol 2008;70:194-202.

60 Agrawal V, Krause KR, Chengelis DL, Zalesin KC, Rocher LL, McCullough PA: Relation between degree of weight loss after bariatric surgery and reduction in albuminuria and C-reactive protein. Surg Obes Relat Dis 2009;5:20-26.

-61 Blanco S, Vaquero M, Gomez-Guerrero C, Lopez D, Egido J, Romero R: Potential role of angiotensin-converting enzyme inhibitors and statins on early podocyte damage in a model of type 2 diabetes mellitus, obesity, and mild hypertension. Am J Hypertens 2005; 18:557-565.

62 de Paula RB, da Silva AA, Hall JE: Aldosterone antagonism attenuates obesity-induced hypertension and glomerular hyperfiltration. Hypertension 2004;43:41-47.

63 Nagase M, Yoshida S, Shibata S, Nagase T, Gotoda T, Ando K, Fujita T: Enhanced aldosterone signaling in the early nephropathy of rats with metabolic syndrome: possible contribution of fat-derived factors. J Am Soc Nephrol 2006;17:3438-3446.

64 Nagase M, Matsui H, Shibata S, Gotoda T, Fujita T: Salt-induced nephropathy in obese spontaneously hypertensive rats via paradoxical activation of the mineralocorticoid receptor: role of oxidative stress. Hypertension 2007;50:877-883.

65 Nagase M, Fujita T: Aldosterone and glomerular podocyte injury. Clin Exp Nephrol 2008;12:233-242.

66 Nowicki M, Muskala P, Bald E, Chwatko G: Nephroprotective effect of combined converting enzyme and aldosterone blockade in hypertensive patients with target organ damage is blood pressure-dependent. J Am Soc Nephrol 2003; 14:21A.

67 Morales E, Huerta A, Gutierrez-Solis E, Gutierrez E, Polanco N, Gutierrez-Millet V, Gonzalez E, Praga M: Antiproteinuric effect of renin-angiotensin-aldosterone system (RAAS) in obese patients. Which is the most effective option? J Am Soc Nephrol 2008;19: 549A.

68 Vasan RS, Evans JC, Larson MG, Wilson PW, Meigs JB, Rifai N, Benjamin EJ, Levy D: Serum aldosterone and the incidence of hypertension in nonhypertensive persons. N Engl J Med 2004;351:33-41.

69 Frey FJ, Odermatt A, Frey BM: Glucocorticoid-mediated mineralocorticoid receptor activation and hypertension. Curr Opin Nephrol Hypertens 2004;13:451-458.

70 Brunner HR, Laragh JH, Baer L, Newton MA, Goodwin FT, Krakoff LR, Bard RH, Buhler FR: Essential hypertension: renin and aldosterone, heart attack and stroke. N Engl J Med 1972;286:441-449. 